from the tattooed skin areas (this expresses the changing capacity for wool production better than it would be expressed as weight per unit area of skin). Results obtained so far may be summarized as follows :

(1) Results agreed with those of Hart in supporting the 'contrast sensitivity' theory of response in wool growth to photoperiodic stimuli.

(2) Although at the end of the pre-experimental period the sheep in the experimental group had produced less clean wool from their marked areas than that grown by the marked regions of the controls, during the period August-September 1955 they had begun to produce a significantly greater weight of wool than that grown by the controls. There continued to be a margin between the two groups until during March-May 1956 the experimental group reached a peak, producing about 48 per cent more wool than the controls. The margin between the two groups was then gradually reduced through the summer until October of the same year (1956). The remarkable rise in production of clean wool (approximately 50 per cent more than the controls) by the experimental animals during the two months (October-December) immediately following the conclusion of the experimental period indoors is shown in Fig. 1. This occurred in spite of the fact that (a) wool production of the control animals had declined, $(b)$ the value of the pasture was beginning to deteriorate at this season, and (c) both control and experimental animals were now together outdoors under the same conditions. During the following period, DecemberFebruary, the margin, although slightly reduced, was still high. Sampling will continue and it is hoped to elucidate further the responses in these and other sheep. It is clear, however, that this high production during four months of what is normally a low wool-producing season has significant practical implications.

(3) The difference in wool production between the two groups changed significantly with time during the experiment (groups $\times$ times interaction significant at the 0.1 per cent level).

(4) Seasonal variations in wool production have been described before : again in this experiment a seasonal variation with a peak each summer has been demonstrated by both groups while they were housed, and the variation is independent of either level of feed or photoperiodicity.

(5) The curve for mean monthly ambient air temperatures was closely followed by those for clean-wool production of both groups throughout the experiment. It is not certain that external temperature had an immediate and direct effect on seasonal variation in wool production, but it is probable that variation in temperature was a contributory factor.

(6) From a wool-production point of view, rams and rigs behaved no differently from the wethers.

I am grateful to Dr. D. P. Cuthbertson, director, J. C. Gill, J. Wood and others on the staff of the Rowett Research Institute for facilities and maintenance of sheep during the experiment; also to R. Bell for statistical analyses and to Mrs. S. Webster, research assistant in this Department, for her skill and care in recording data and other work connected with the investigation.

Biology Department,

A. B. WILDMAN

Wool Industries Research Asscciation,

Leeds. April 18. 'Yeates, N. T. M., J. Agric. Sci., \{9, 1 (1949); Aust. J. Agric. Res.,
7, No. 5, 440 (1956).

${ }^{2}$ Hart, D. S., Nature, 171, 133 (1953).

${ }^{3}$ Hart, D. S., Proc. N.Z. Soc. An. Prod., 15, 57 (1955).

\section{Anisotropy of Sclerotinites}

SEYLER ${ }^{1}$ has measured the reflectance of sclerotinites but has not commented upon the existence of anisotropy in them.

I have found distinct anisotropy in some sclerotinites obtained from coals of widely different geological periods and of widely scattered areas throughout the world. Reflectance measurements have been made in oil and the relation of maximum reflectance $\left(R_{1}\right)$ to minimum reflectance $\left(R_{2}\right)$ has been plotted in Fig. 1. For comparison, the measurements of $R_{1}$ and $R_{2}$ in respect of vitrinites of different ranks obtained by Broadbent and Shaw ${ }^{2}$ have been plotted in the same figure. It will be seen that this relation with sclerotinites and vitrinites appears to follow a straight line up to the $R_{1}$ value of about 3 per cent. At this stage the results with vitrinite deviate from the linear relation.

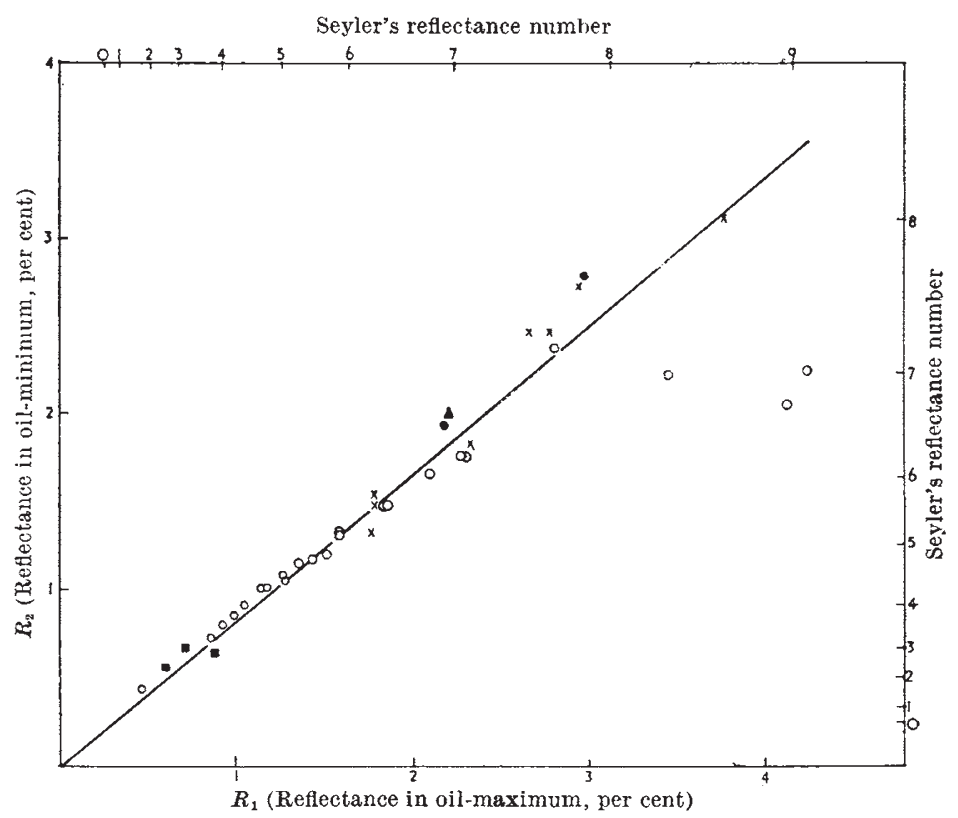

Fig. 1. Relation of maximum $\left(\boldsymbol{R}_{1}\right)$ and minimum reflectance $\left(\boldsymbol{R}_{2}\right)$ in oil for sclerotinite and vitrinite. Sclerotinite: , Carboniferous, Barnesley seam, England; , Carboniferous, Harraton Small, England; $\times$, Permo-carboniferous, Wankie Vitrinite: $O$, British carboniferous coals

It will be of interest to ascertain if the values of $R_{1}$ and $R_{2}$ for other micro-constituents of coal follow similar relations.

British Coal Utilisation Research Association,

Randalls Road, Leatherhead, Surrey. April 1.

${ }^{1}$ Seyler, C. A., Proc. South Wales Inst. Eng., 63, 213 (1948).

${ }_{2}$ Broadbent, S. R., and Shaw, A. J., Fuel, 34, 385 (1955). 